\title{
Variation of Wheat Cultivars in Their Response to Elevated Temperature on Starch and Dry Matter Accumulation in Grain
}

\author{
Soyema Khatun, ${ }^{1}$ Jalal Uddin Ahmed, ${ }^{2}$ Tofazzal Hossain, ${ }^{2}$ \\ M. Rafiqul Islam, ${ }^{3}$ and Mohammed Mohi-Ud-Din ${ }^{2}$ \\ ${ }^{1}$ Bangladesh Institute of Nuclear Agriculture, Bangabandhu Sheikh Mujibur Rahman Agricultural University, \\ Salna, Gazipur 1706, Bangladesh \\ ${ }^{2}$ Department of Crop Botany, Bangabandhu Sheikh Mujibur Rahman Agricultural University, Salna, Gazipur 1706, Bangladesh \\ ${ }^{3}$ Department of Agronomy, Bangabandhu Sheikh Mujibur Rahman Agricultural University, Salna, Gazipur 1706, Bangladesh
}

Correspondence should be addressed to Soyema Khatun; soyemabina14@yahoo.com

Received 15 November 2015; Accepted 17 January 2016

Academic Editor: Kent Burkey

Copyright (c) 2016 Soyema Khatun et al. This is an open access article distributed under the Creative Commons Attribution License, which permits unrestricted use, distribution, and reproduction in any medium, provided the original work is properly cited.

\begin{abstract}
Three wheat cultivars, namely, BARI Gom 25, BARI Gom 26, and Pavon 76, were sown in experimental field of Bangabandhu Sheikh Mujibur Rahman Agricultural University, Gazipur, in Bangladesh, on 18 November, 2013. Two temperature regimes, namely, normal $\left(23^{\circ} \mathrm{C}\right.$ in open field) and elevated $\left(6 \pm 1^{\circ} \mathrm{C}\right.$ higher compared to open field mean air temperature in polythene chamber) temperature, were created immediately after anthesis to investigate the response of wheat cultivars to heat stress. Elevated temperature cuts back the duration of grain filling by 5 days in BARI Gom 25 and BARI Gom 26 and 10 days in Pavon 76. Starch synthesis was also cut back by the same duration in respective cultivars under elevated temperature condition. Results indicate that failure of conversion of sugar to starch rather than limited supply of sugar under high temperature condition was responsible for shortening of grain filling duration in all wheat cultivars. However, the response of elevated temperature on grain starch and main stem grain dry matter was less profound in BARI Gom 25 and BARI Gom 26 compared to Pavon 76 indicating their better tolerance to elevated temperature.
\end{abstract}

\section{Introduction}

Wheat generally grows within an optimum temperature range of 15 to $18^{\circ} \mathrm{C}$ [1] but the temperature requirement of the crop during reproductive growth phases lies within $22^{\circ} \mathrm{C}$ for optimizing its grain yield [2]. Under Bangladesh condition the possibility to achieve high genetic yield potential of wheat is extremely slim, because the crop cannot complete the major portion of grain filling period before the temperature rises up to the critical level, even if it is planted within early recommended sowing date. In case of late sowing, temperature becomes stressful above $26^{\circ} \mathrm{C}$ when a premature ripening of wheat takes place [3] producing poorly developed grain of wheat [4]. Post-anthesis heat stress environment induces several physiological disorders in wheat, which as a consequence initiates early onset of senescence [5] and slows down conversion of sugar to starch in developing grain of wheat. Due to terminal heat stress eventually smaller number and size of grain are produced [6]. Heat stress also affects cell division and cell enlargement of grain, causing smaller grain number per spike, grain weight per main stem, and finally reduced grain yield [7]. Thus heat stress causes a large yield penalty through reduction of grain filling period in spite of increasing grain filling rate [4].

Under Bangladesh condition a large number of findings are available regarding late planting induced heat stress effect on grain yield and yield attributes [8]. In all of them, the temperature regimes were created by seeds sown on different sowing dates. There are fewer reports so far in which two temperature regimes were created by seeds sown on the same day to study the response to terminal heat stress. Such results possibly have included effects of some coexisting climatic factors apart from late seeding heat stress by itself like infestation of foliar diseases, frequent crop lodging due to high wind velocity together with early monsoon rainfall, and so forth.

The present experiment was undertaken to investigate the physiological basis of grain starch and dry matter accumulation pattern under high temperature conditions in recently 
released wheat varieties by excluding the possible effects of climatic factors on late seeding wheat varieties.

\section{Materials and Methods}

The experiment was conducted at the research farm of Bangabandhu Sheikh Mujibur Rahman Agricultural University, Gazipur, in Bangladesh, during November, 2013, to April, 2014, using split plot design with four replications under two growing conditions, namely, open field temperature and elevated temperature (polythene chamber). Recently released two potential heat tolerant wheat cultivars, namely, BARI Gom 25 and BARI Gom 26, along with a heat sensitive check wheat cultivar Pavon 76 were used in this study. Seeds were sown on 18 November, 2011, in rows of $20 \mathrm{~cm}$ apart (at the rate of $120 \mathrm{~kg} \mathrm{ha}^{-1}$ ). The unit plot size was $3 \mathrm{~m} \times 3 \mathrm{~m}$ having a plot-to-plot distance of $1.0 \mathrm{~m}$. In each of these $3 \mathrm{~m} \times 3 \mathrm{~m}$ plots, $1.5 \mathrm{~m} \times 1.0 \mathrm{~m}$ area was covered by transparent polythene sheet. The chambers were constructed using bamboo frame of $1.5 \mathrm{~m}$ high keeping $30 \mathrm{~cm}$ open space near the ground surface. Light intensity during maximum grain filling was found to be $1280 \mu \mathrm{mol} \mathrm{m}^{-2} \mathrm{~S}^{-1}$ in open field and $950 \mu \mathrm{mol} \mathrm{m}^{-2} \mathrm{~S}^{-1}$ in polythene chamber which is higher than its normal light intensity. Normal light intensity requirement for wheat was $610 \mu \mathrm{mol} \mathrm{m}^{-2} \mathrm{~S}^{-1}$ reported by Gerbaud and Andre [9]. Cow dung (8500 $\mathrm{kg} \mathrm{ha}^{-1}$ ) and other fertilizers such as $\mathrm{N} 60 \mathrm{~kg} \mathrm{ha}^{-1}$ (as Urea), P $140 \mathrm{~kg} \mathrm{ha}^{-1}$ (as TSP), K $100 \mathrm{~kg} \mathrm{ha}^{-1}$ (as MOP), and $\mathrm{S} 110 \mathrm{~kg} \mathrm{ha}^{-1}$ (as Gypsum) were applied as per recommendation [10]. Irrigation was given to maintain more or less a field capacity and to avoid the drought stress.

Mean air temperature was recorded every day at noon period ( $2 \mathrm{pm}$ to $3 \mathrm{pm}$ ) using maximum-minimum thermometer from 5 days after anthesis (DAA) up to the maturity of each cultivar. Main shoot of 100 individual plants was tagged to confirm the equal exposure of elevated temperature starting the first appearance of anther emerging from the spike in each plant. Tagged ten spikes of main shoots were sampled at 5-day intervals starting from anthesis to $40 \mathrm{DAA}$ and sampled spikes were oven-dried at $70^{\circ} \mathrm{C}$ for 72 hours. After oven-drying grains were sampled from the middle portion of the spike and their weight was taken with analytical balance (Model: AGN220C). The grain samples were used for sugar and starch analysis. Soluble sugar and starch content of grain was determined using the method of Yoshida et al. [11]. Plants were hand-harvested by cutting them at ground level. Then grain number per spike and main stem grain dry weight were measured.

All statistical analyses were performed by MSTAT-C program. The treatment means were compared using Duncan's Multiple Range Test (DMRT) at 5\% level of significance. Graphical representation and simple data were calculated by using Microsoft Excel.

\section{Results}

Wheat cultivars were grown in open field temperature condition where daily mean temperature during reproductive growth stage was recorded $23^{\circ} \mathrm{C}$ (ranging from 18.5 to $25.5^{\circ} \mathrm{C}$ )

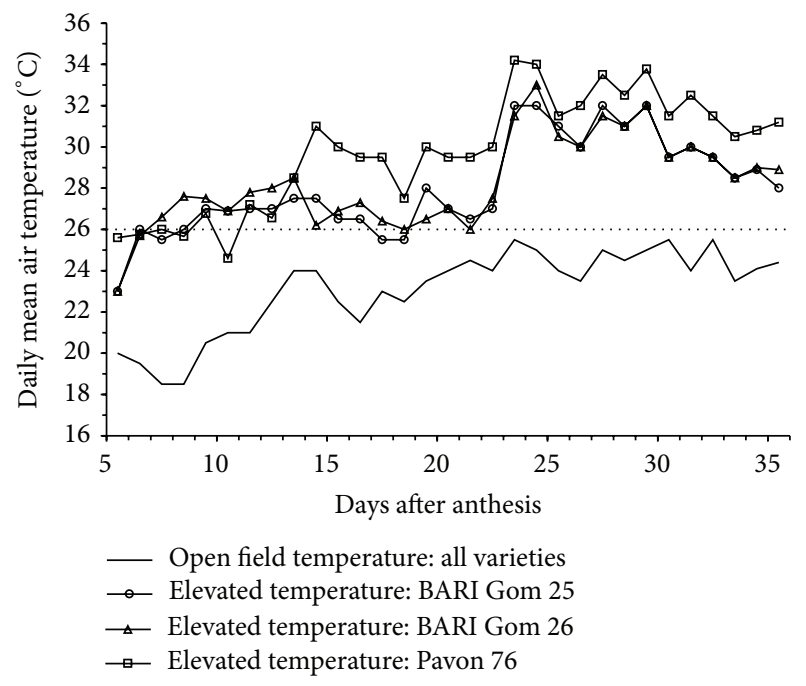

FIGURE 1: Daily mean air temperature received by three wheat cultivars from 5 to 35 DAA under open field and elevated temperature conditions. Horizontal dotted line indicates the critical level of temperature for grain growth of wheat.

(Figure 1). But under elevated temperature condition in polythene chamber the daily mean temperature was raised by $6 \pm$ $1^{\circ} \mathrm{C}$ compared to open field mean air temperature. Elevated temperature condition accelerated the physiological maturity of all wheat cultivars and hence reduced their grain filling duration (Figure 2). Under elevated temperature condition grain filling duration was 25 days in Pavon 76 and 30 days in BARI Gom 25 and BARI Gom 26. But under open field temperature condition grain filling duration in all wheat cultivars was 35 days. The results indicate that extent of reduction of grain filling duration was 5 days in BARI Gom 25 and BARI Gom 26 and 10 days in Pavon 76.

Because of similar variation of grain filling duration out of two wheat cultivars BARI Gom 25 and BARI Gom 26, finally BARI Gom 26 was taken to be compared with Pavon 76 for grain starch and soluble sugar analysis. At physiological maturity individual grain weight and starch content were reduced in all cultivars under elevated temperature condition (Figures 3(a) and 3(b)). Maximum reduction was observed in Pavon 76. Results indicate that starch synthesis duration as well as grain filling duration was similar (35-day) in BARI Gom 26 and Pavon 76 under open field temperature condition (Figure 4(a)). On the other hand under elevated temperature condition starch synthesis duration and grain filling duration both were reduced by 5 days in BARI Gom 26 and 10 days in Pavon 76 (Figure 4(a)). Thus compared to BARI Gom 26, starch synthesis was stopped about 5 days earlier in Pavon 76 due to elevated temperature condition. A higher level of grain soluble sugar was found up to 20 DAA in BARI Gom 26 under open field temperature condition compared to elevated temperature condition, which was found in Pavon 76 for 15 days (Figure 4(b)). Afterwards soluble sugar content was lower under open field temperature condition compared to elevated temperature condition in both cultivars. In a separate experiment Hasan and Ahmed [4] also reported almost 

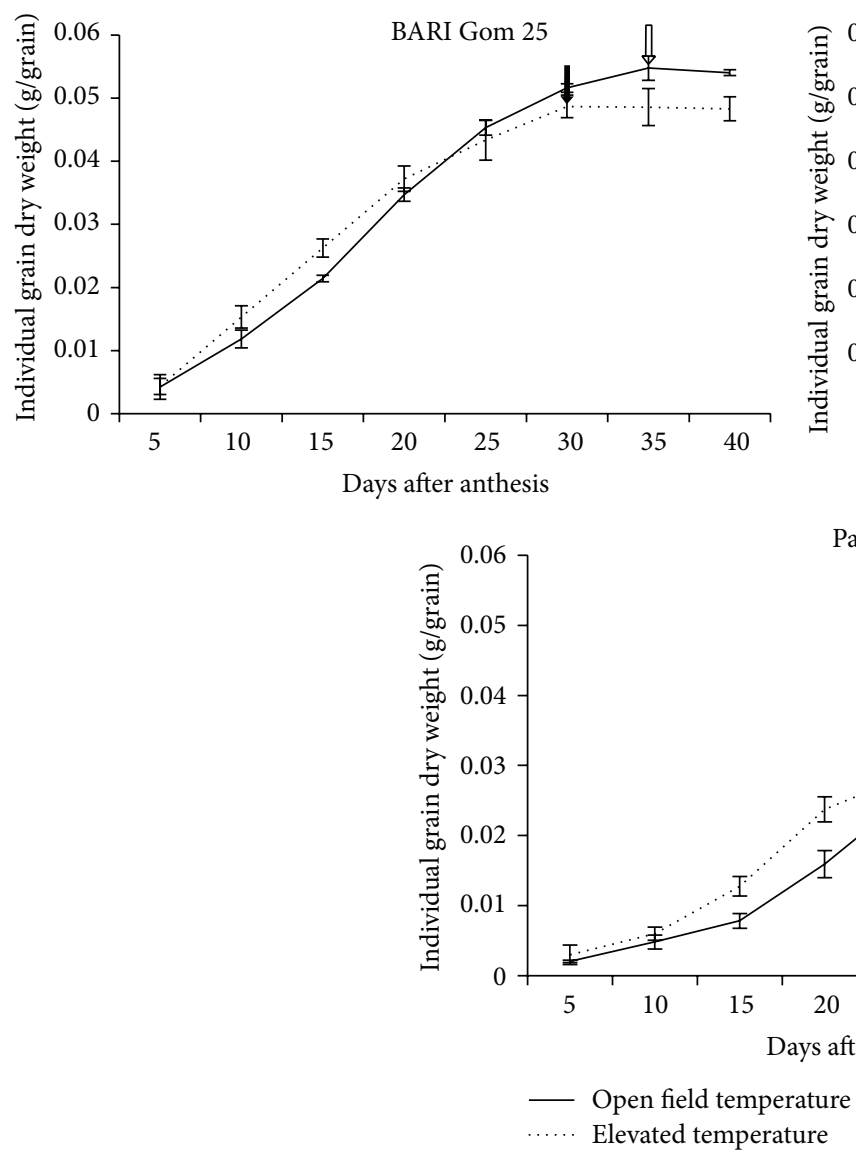

Open field temperature

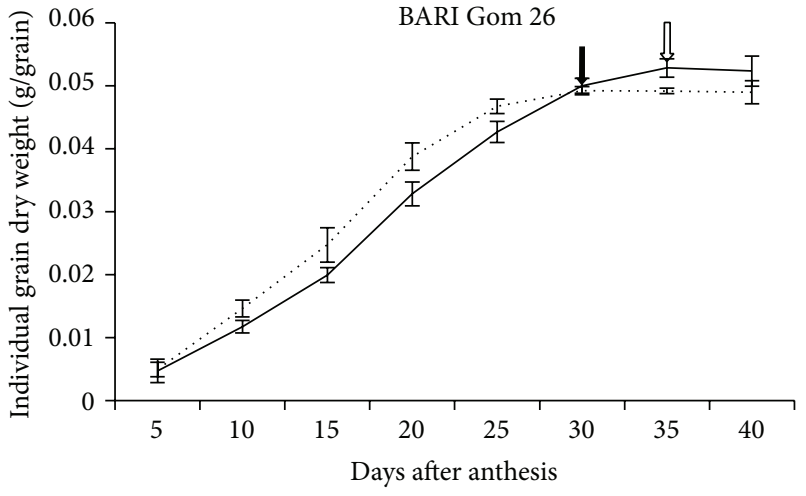

Pavon 76

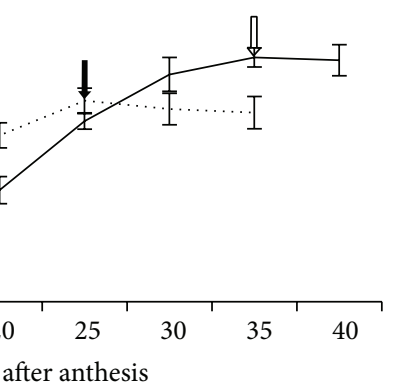

-

FIGURE 2: Individual grain dry weight of three wheat cultivars under open field and elevated temperature conditions at different days after anthesis. Unfilled and filled arrows indicate physiological maturity of wheat cultivars under open field and elevated temperature conditions, respectively. Vertical lines are standard errors of selected data point.

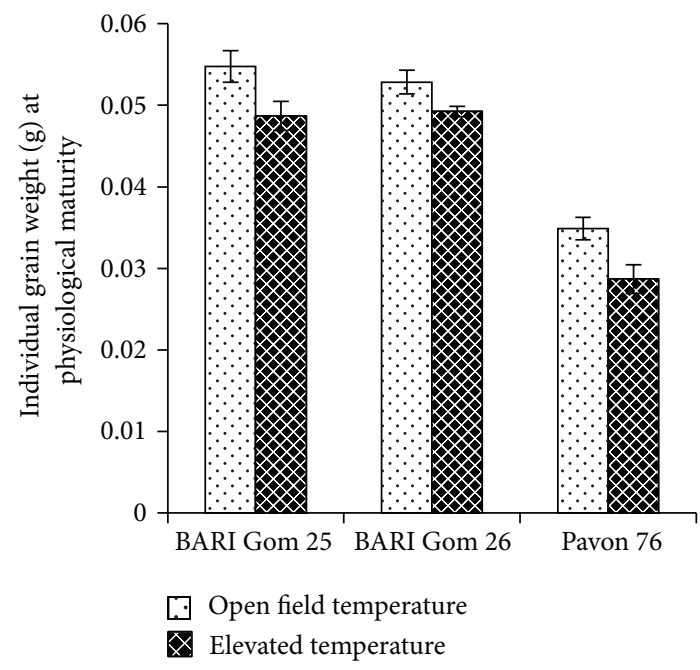

(a)

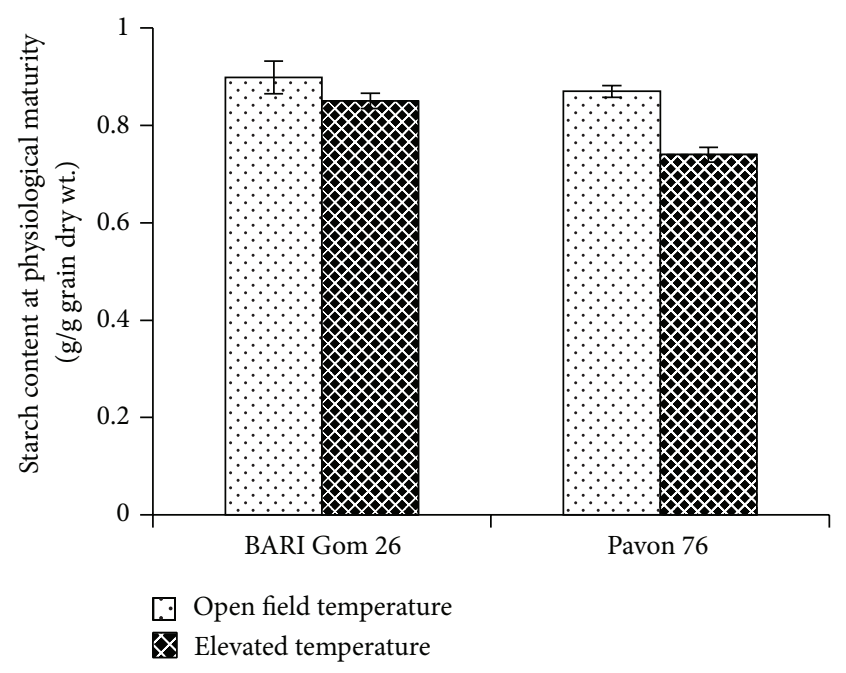

(b)

FIGURE 3: (a) Individual grain weight in three wheat cultivars and (b) starch content in two cultivars at physiological maturity under open field and elevated temperature conditions. Vertical lines are standard errors of mean data point. 

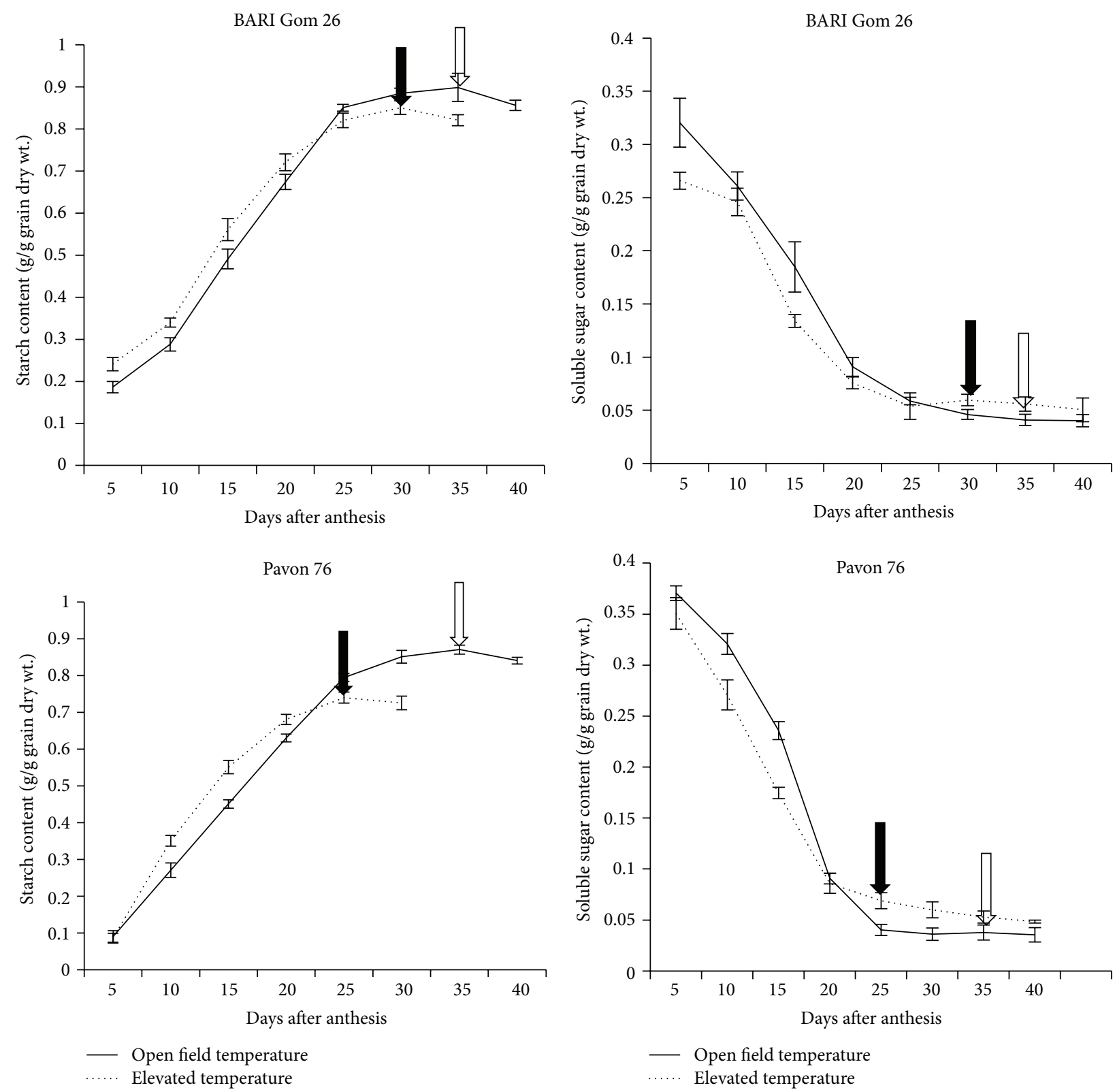

(a)

(b)

FIGURE 4: (a) Starch and (b) soluble sugar content in grain of two wheat cultivars from 5 DAA to maturity under open field and elevated temperature conditions. Unfilled and filled arrows indicate physiological maturity of wheat cultivars under open field and elevated temperature conditions, respectively. Vertical lines are standard errors of selected data point.

a similar report with a difference that the different seeding dates were varied for inducing heat stress. In such a case regular of fungicide was done to control in late seeded crop to control foliar disease. In the present experiment foliar disease infestation was apparently absent.

Compared to open field temperature condition, maximum reduction of number of grain per spike was recorded in Pavon 76 (25\%) (Table 1) whereas the minimal reduction was the rest of cultivars under elevated temperature condition. The maximum reduction of main stem grain weight was recorded in Pavon 76 (22\%) and minimum in BARI Gom 26 (8\%) (Table 2) under elevated temperature condition.

\section{Discussion}

Under elevated temperature condition the daily mean temperature was higher in all wheat cultivars as compared with open field temperature. Among all the cultivars under elevated temperature condition cultivar Pavon 76 received further elevated temperature due to its delay in anthesis by a week compared to that of BARI Gom 25 and BARI Gom 26. Although anthesis occurred at different dates in different cultivars in all cases grain development took place at temperature exceeding the higher limits of optimum temperature particularly at late stages after anthesis in all cultivars under 
TABLE 1: Number of grain per spike in three wheat cultivars under open field and elevated temperature conditions.

\begin{tabular}{lccc}
\hline Cultivar & Open field temperature & $\begin{array}{c}\text { Number of grain/spike } \\
\text { Elevated temperature }\end{array}$ & RP* $^{*}(\%)$ \\
\hline BARI Gom 25 & $43.43 \pm 0.42^{\mathrm{c}}$ & $41.03 \pm 0.30^{\mathrm{c}}$ & 6 \\
BARI Gom 26 & $55.58 \pm 0.35^{\mathrm{a}}$ & $47.65 \pm 0.50^{\mathrm{b}}$ & 14 \\
Pavon 76 & $56.38 \pm 0.48^{\mathrm{a}}$ & $42.48 \pm 0.50^{\mathrm{c}}$ & 25 \\
\hline
\end{tabular}

${ }^{*} \mathrm{RP}=$ reduction percentage relative to open field temperature condition.

The values have been given as arithmetic mean \pm SE. Values in a column with different letters are significantly different at $P \leq 0.05$ by DMRT.

TABLE 2: Grain weight per main stem in three wheat cultivars under open field and elevated temperature conditions.

\begin{tabular}{lccc}
\hline Cultivar & \multicolumn{2}{c}{ Main stem grain weight (g) } & \\
& $\begin{array}{c}\text { Open field } \\
\text { temperature }\end{array}$ & $\begin{array}{c}\text { Elevated } \\
\text { temperature }\end{array}$ & RP* $\left.^{*} \%\right)$ \\
\hline BARI Gom 25 & $2.15 \pm 0.11^{\mathrm{c}}$ & $1.92 \pm 0.12^{\mathrm{d}}$ & 11 \\
BARI Gom 26 & $2.62 \pm 0.13^{\mathrm{a}}$ & $2.40 \pm 0.12^{\mathrm{b}}$ & 8 \\
Pavon 76 & $2.00 \pm 0.14^{\mathrm{d}}$ & $1.59 \pm 0.14^{\mathrm{e}}$ & 22 \\
\hline
\end{tabular}

${ }^{*} \mathrm{RP}=$ reduction percentage relative to open field temperature condition. The values have been given as arithmetic mean \pm SE. Values in a column with different letters are significantly different at $P \leq 0.05$ by DMRT.

elevated temperature condition. The optimum temperature for reproductive stages of wheat generally was reported within a range of 22 to $26^{\circ} \mathrm{C}[2,3,12,13]$.

So under elevated temperature condition, the temperature exceeded the optimum range of temperature for wheat cultivar. The elevated temperature caused a premature ripening of wheat grain and in cutback the grain filling duration of wheat cultivar by 10-day in Pavon 76 in contrast to 5-day in BARI Gom 25 and BARI Gom 26 (Figure 2). Varietal differences in reduction of grain filling duration were reported indicating a larger reduction in heat sensitive cultivars compared to heat tolerant wheat cultivars $[4,14]$. Although at early reproductive stage the individual grain dry matter accumulation was slightly favored by elevated temperature condition in all wheat cultivars but the later stages of postanthesis period, Pavon 76 stopped its grain dry matter accumulation earlier than the other two wheat cultivars. Finally at physiological maturity a significant reduction of individual grain weight and starch content was recorded in Pavon 76 under elevated temperature condition (Figures 3(a) and $3(b)$ ). Elevated temperature reduced the grain filling duration which was associated with a reduction in individual grain weight $[15,16]$.

The grain starch synthesis was also cut back by 5 days in BARI Gom 26 but 10 days in Pavon 76 (Figure 4(a)). Coincidence of duration was also observed in premature of individual grain dry matter accumulation in all wheat cultivars under elevated temperature condition. It was apparent that individual grain dry matter accumulation was contributed by grain starch accumulation [17]. At physiological maturity significant reduction of grain starch content was recorded in Pavon 76 under elevated temperature condition, whereas such reduction was not significant in BARI Gom 26 (Figure 3(b)). It is clearly noticed that the grain starch synthesis was terminated in presence of adequate amount of grain soluble sugar under elevated temperature condition. The results clearly indicate that grain soluble sugar content under elevated temperature condition had slight influence on early termination of grain starch content. Premature of grain development under heat stress condition had been reported due to limited enzymatic function involving sugar to starch conversion [18-20]. It appeared here that elevated temperature restricted starch synthesis more prominent in heat sensitive cultivars compared to heat tolerant cultivars $[4,21]$.

Grain weight per main stem was partly contributed by grain number and partly by individual grain weight which was the most sensitive to elevated temperature in Pavon 76 among all wheat cultivars tested in this experiment. Exposure to high temperature above $30^{\circ} \mathrm{C}$ during 10 to 14 days after anthesis has been reported to contribute to the reduction of grain number in wheat by affecting primarily cell division and subsequently cell enlargement [7]. Significant reduction in grain number in different wheat cultivars under elevated temperature was also found by Viswanathan and KhannaChopra [22]; Sial et al. [23]; and Tahir and Nakata [24]. Finally the wheat cultivars like BARI Gom 25 and BARI Gom 26 with longer grain filling duration produced significantly higher amount of main stem grain weight under elevated temperature condition than the cultivar Pavon 76 (Table 2). Increasing temperature (from 30 to $38^{\circ} \mathrm{C}$ ), during reproductive phase, reduced the main stem grain weight by 20 to $44 \%$ [24]. A significant reduction in main stem grain weight difference in five wheat cultivars had been reported by Fokar et al. [6]. However, in the present experiment, the reduction of main stem grain weight was 8 to $22 \%$ by raising daily mean temperature from $23^{\circ} \mathrm{C}$ to $29^{\circ} \mathrm{C}$ during postanthesis period. In the present experiment the smaller reduction of main stem grain weight was perhaps due to less increase of temperature above the optimum range $\left(22^{\circ} \mathrm{C}\right.$ to $\left.26^{\circ} \mathrm{C}\right)$ as compared to large increase of temperature from $30^{\circ} \mathrm{C}$ to $38^{\circ} \mathrm{C}$ reported by Tahir and Nakata [24].

Finally the elevated temperature during postanthesis period had more deleterious effect in heat sensitive cultivar Pavon 76. On the other hand the minimal effect of elevated temperature in BARI Gom 25 and BARI Gom 26 was due to their inherent capacity to tolerate elevated temperature during postanthesis period.

\section{Disclosure}

This work was conducted as part of MS thesis of the first author for Bangabandhu Sheikh Mujibur Rahman Agricultural University, Salna, Gazipur. 


\section{Conflict of Interests}

The authors declare that there is no conflict of interests regarding the publication of this paper.

\section{Acknowledgment}

The authors are grateful for the university authority for help rendering during this study.

\section{References}

[1] S. I. Chowdhury and I. F. Wardlaw, "The effect of temperature on kernel development in cereals," Australian Journal of Agricultural Research, vol. 29, no. 2, pp. 205-223, 1978.

[2] C. A. Campbell and D. W. L. Read, "Influence of air temperature, light intensity and soil moisture on the growth, yield and some growth analysis characteristics of chinook wheat grown in the growth chamber," Canadian Journal of Plant Science, vol. 48, no. 3, pp. 299-311, 1968.

[3] Y. P. Aborl, A. K. Bagga, N. V. K. Chakravarty, and P. N. Wattal, "Impact of rise in temperature on the productivity of wheat in India," in Impact of Global Climatic Change on Photosynthesis and Plant Productivity, Y. P. Abrol, P. N. Wattal, A. Gnanam, Govindjee, D. R. Ort, and A. H. Teramura, Eds., pp. 787-798, Oxford and IBH Publishing, New Delhi, India, 1991.

[4] M. A. Hasan and J. U. Ahmed, "Kernel growth physiology of wheat under late planting heat stress," Journal of the National Science Foundation of Sri Lanka, vol. 33, no. 3, pp. 193-204, 2005.

[5] M. Mohi-ud-din, M. A. Rahman, and J. U. Ahmed, "Changes in SPAD value and soluble carbohydrate concentration during senescence of wheat flag leaf under heat stressed environment," Journal of the Asiatic Society of Bangladesh, Science, vol. 33, no. 2, pp. 121-130, 2007.

[6] M. Fokar, A. Blum, and H. T. Nguyen, "Heat tolerance in spring wheat. II. Grain filling," Euphytica, vol. 104, no. 1, pp. 9-15, 1998.

[7] L. R. Gibson and G. M. Paulsen, "Yield components of wheat grown under high temperature stress during reproductive growth," Crop Science, vol. 39, no. 6, pp. 1841-1846, 1999.

[8] S. Sikder and N. K. Paul, "Effects of post-anthesis heat stress on stem reserves mobilization, canopy temperature depression and floret sterility of wheat cultivars," Bangladesh Journal of Botany, vol. 39, no. 1, pp. 51-55, 2010.

[9] A. Gerbaud and M. Andre, "Effect of $\mathrm{CO}_{2}, \mathrm{O}_{2}$, and light on photosynthesis and photorespiration in wheat," Plant Physiology, vol. 66, no. 6, pp. 1032-1036, 1980.

[10] Yearbook of Agricultural Statistics of Bangladesh, Bangladesh Bureau of Statistics, Ministry of planning and Government of the People's Republic of Bangladesh, 2005.

[11] S. Yoshida, D. A. Forno, J. H. Cock, and K. A. Gomez, Laboratory Manual for Physiological Studies of Rice, The International Rice Research Institute, Los Banos, Calif, USA, 3rd edition, 1976.

[12] M. Mullarkey and P. Jones, "Isolation and analysis of thermotolerant mutants of wheat," Journal of Experimental Botany, vol. 51, no. 342, pp. 139-146, 2000.

[13] H. Tewolde, C. J. Fernandez, and C. A. Erickson, "Wheat cultivars adapted to post-heading high temperature stress," Journal of Agronomy and Crop Science, vol. 192, no. 2, pp. 111-120, 2006.

[14] A. S. Dias and F. C. Lidon, "Evaluation of grain filling rate and duration in bread and durum wheat, under heat stress after anthesis," Journal of Agronomy and Crop Science, vol. 195, no. 2, pp. 137-147, 2009.

[15] I. J. Warrington, R. L. Dunstone, and L. M. Green, “Temperature effects at three development stages on the yield of the wheat ear," Australian Journal of Agricultural Research, vol. 28, no. 1, pp. 1127, 1977.

[16] L. Shpiler and A. Blum, "Differential reaction of wheat cultivars to hot environments," Euphytica, vol. 35, no. 2, pp. 483-492, 1986.

[17] J. H. J. Spiertz, R. J. Hamer, H. Xu, C. Primo-Martin, C. Don, and P. E. L. van der Putten, "Heat stress in wheat (Triticum aestivum L.): effects on grain growth and quality traits," European Journal of Agronomy, vol. 25, no. 2, pp. 89-95, 2006.

[18] K. Denyer, C. Hylton, and A. Smith, "The effect of high temperature on starch synthesis and the activity of starch synthase," Australian Journal of Plant Physiology, vol. 21, no. 6, pp. 783-789, 1994.

[19] C. F. Jenner, "Starch synthesis in the kernel of wheat under high temperature conditions," Australian Journal of Plant Physiology, vol. 21, no. 6, pp. 791-806, 1994.

[20] L. C. MacLeod and C. M. Duffus, "Reduced starch content and sucrose synthase activity in developing endosperm of barley plants grown at elevated temperatures," Australian Journal of Plant Physiology, vol. 15, no. 3, pp. 367-375, 1988.

[21] J. Yang, R. G. Sears, B. S. Gill, and G. M. Paulsen, "Genotypic differences in utilization of assimilate sources during maturation of wheat under chronic heat and heat shock stresses," Euphytica, vol. 125, no. 2, pp. 179-188, 2002.

[22] C. Viswanathan and R. Khanna-Chopra, "Effect of heat stress on grain growth, starch synthesis and protein synthesis in grains of wheat (Triticum aestivum L.) varieties differing in grain weight stability," Journal of Agronomy and Crop Science, vol. 186, no. 1, pp. 1-7, 2001.

[23] M. A. Sial, M. A. Arain, S. Khanzada, M. H. Naqvi, M. U. Dahot, and N. A. Nizamani, "Yield and quality parameters of wheat genotypes as affected by sowing dates and high temperature stress," Pakistan Journal of Botany, vol. 37, no. 3, pp. 575-584, 2005.

[24] I. S. A. Tahir and N. Nakata, "Remobilization of nitrogen and carbohydrate from stems of bread wheat in response to heat stress during grain filling," Journal of Agronomy and Crop Science, vol. 191, no. 2, pp. 106-115, 2005. 


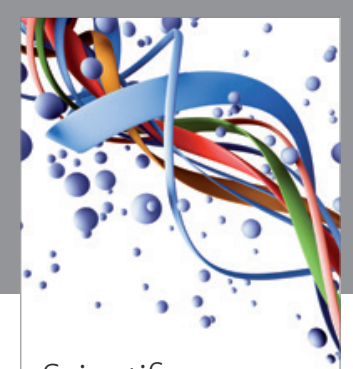

Scientifica
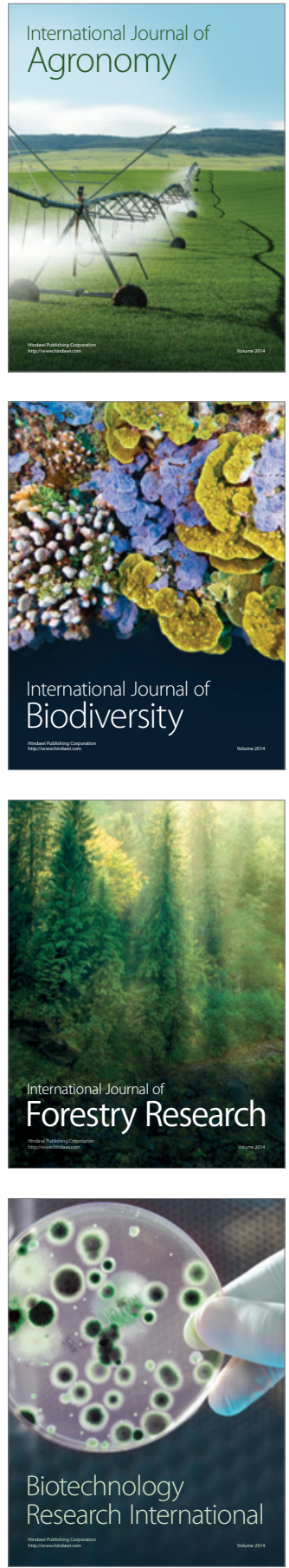
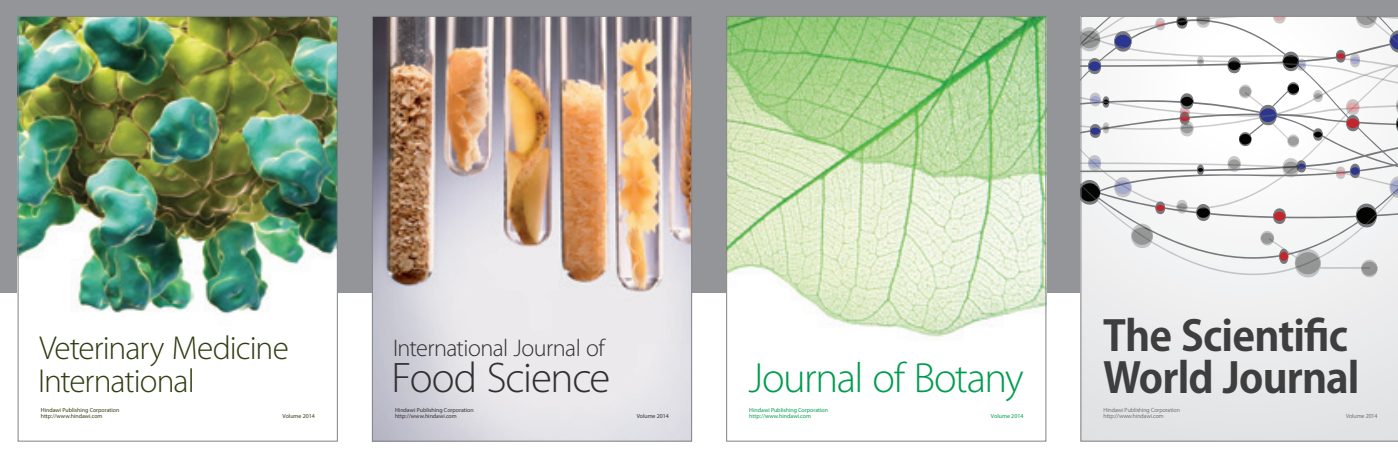

The Scientific

\section{World Journal}

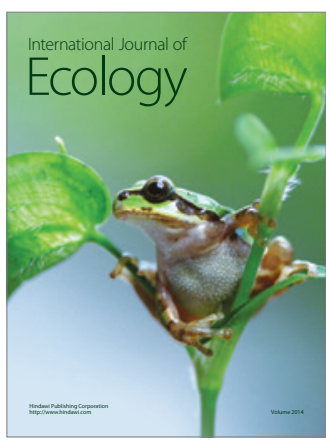

\section{Hindawi}

Submit your manuscripts at

http://www.hindawi.com
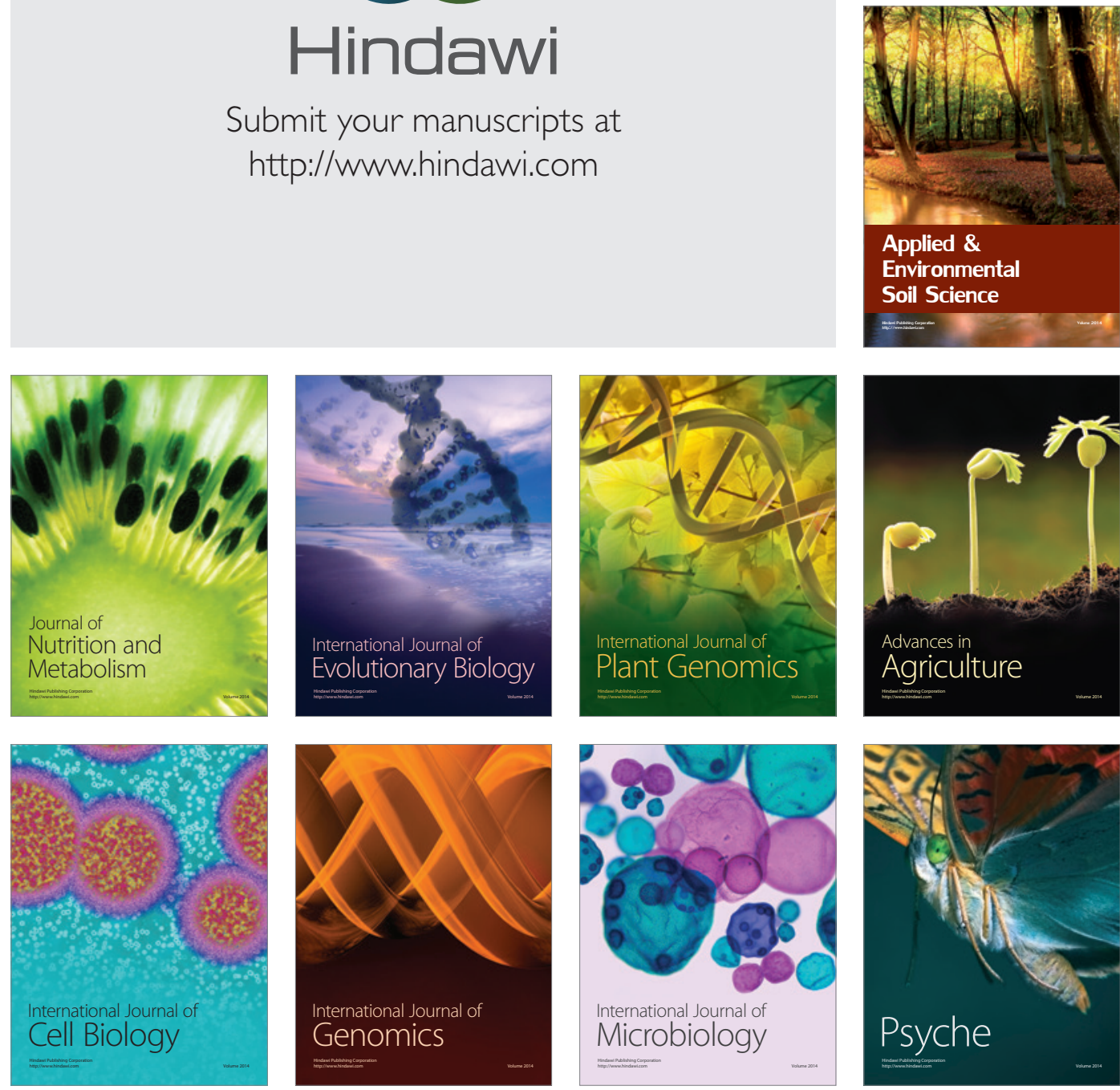
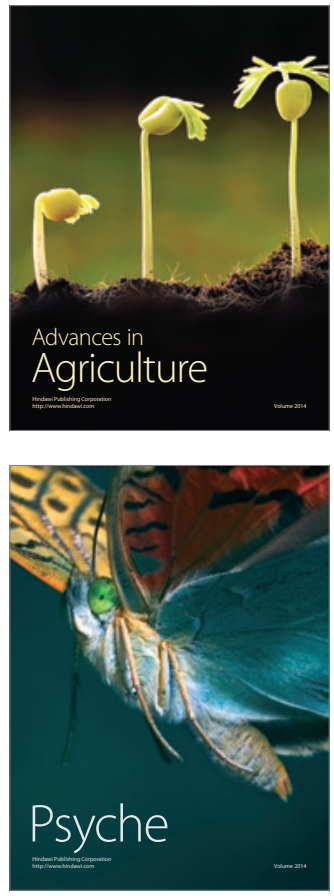